\title{
AMYLOID DISEASE COMPLICATING ANKYLOSING SPONDYLITIS
}

\author{
BY \\ MARTIN E. H. HALFORD AND C. JUSTIN CLARK \\ From the Department of Morbid Anatomy, Westminster Medical School, \\ and Westminster Hospital, London
}

Wichmann (1893) first described amyloid disease complicating rheumatoid arthritis. Many further reports of this association have been published, and, with the decline in the incidence of severe pulmonary tuberculosis, rheumatoid arthritis may become the commonest cause of amyloidosis in Great Britain. Thus, Fearnley and Lackner (1956) found eight cases of amyloidosis in a series of 183 patients with rheumatoid arthritis, Gedda (1955) found nine cases in a series of 45, and Teilum and Lindahl (1954) found seventeen cases in a series of 28 . Teilum and Lindahl also included two cases of ankylosing spondylitis but no clinical details are recorded.

In the following case amyloid disease, diagnosed clinically, caused death as a result of renal involvement in a man with ankylosing spondylitis.

\section{Case History}

Symptoms of ankylosing spondylitis consisting of lumbar pain and stiffness began in 1942, when the patient was 16 years old. A year later typical radiological changes were present in the sacro-iliac joints (Fig. 1, opposite). The erythrocyte sedimentation rate was $65 \mathrm{~mm}$. in 1 hour. He was immobilized in a plaster bed for a year. In 1945 radiotherapy was given to the thoracic and lumbar spine $(750 \mathrm{r})$ and to each hip joint $(1,000 \mathrm{r})$ with some improvement. In 1950 the patient was admitted to hospital for herniorrhaphy; at this time he had ankylosis of the spine with severe involvement of both hips, proteinuria was noted, and the blood pressure was $140 / 85 \mathrm{~mm}$. Hg. A year later the blood pressure had risen to $160 / 100 \mathrm{~mm}$. Hg. A further course of radiotherapy to the lumbar spine ( $750 \mathrm{r}$ ) and the sacral and cervical areas $(750 \mathrm{r})$ gave relief of symptoms, but the proteinuria persisted, and by June, 1953, the clinical picture of malignant hypertension with left ventricular failure had developed. The blood pressure was now $225 / 145 \mathrm{~mm}$. $\mathrm{Hg}$ and there was bilateral papilloedema with severe retinal changes. The blood urea was $71 \mathrm{mg}$. per cent. After a period of rest in bed and salt restrictio the papilloedema, retinal exudates, and haemorrhages disappeared, and the cardiac asthma was relieved. The hypertension and uraemia persisted and cardiac asthma recurred a year later.

Laboratory Findings.-Blood urea $78 \mathrm{mg}$. per $100 \mathrm{ml}$ serum albumin $3.4 \mathrm{~g}$. per $100 \mathrm{ml}$., serum globulif 3.37 g. per $100 \mathrm{ml}$. Thymol turbidity 1 unit, thymot flocculation 0 , serum colloidal gold reaction 0 gीn sulphate turbidity 3 units, ammonium sulphate mirc bidity 2 units.

Congo red test positive with 78 per cent. dye remợe from serum after 1 hour.

Urine contained $32 \mathrm{mg}$. per $100 \mathrm{ml}$. protein.

Nausea and vomiting were followed by epileptiforn convulsions and a sudden left hemiplegia. The bloo pressure fell to $160 / 100 \mathrm{~mm}$. $\mathrm{Hg}$ and secondary optie atrophy developed. Death occurred suddenly in March을 1955 , from a right cerebral haemorrhage.

There was no significant fever or oedema at any stage of this illness. The urine showed moderate or large amounts of protein on seven occasions, but not when examined in 1950 before the patient's re-admission to hospital for herniorrhaphy. The centrifuged deposi⿺ showed a few red blood cells on three occasions, granulain casts on three occasions, and no abnormality on fou occasions.

Autopsy Findings.-The body was that of a wells nourished young man. There was extensive haemoro rhage in the right frontoparietal region with rupture into the lateral ventricle. A few enlarged lymph node? showed follicular hyperplasia but no amyloid. The lungs showed early bronchopneumonia. The heark $(480$ g.) showed left ventricular hypertrophy. The heart valves and coronary arteries appeared normal. There was early atheroma of the aorta. The liver $(1,380 \mathrm{~g} . \Phi$ was small and showed deposits of amyloid around thథ hepatic arterioles only. The spleen $(120 \mathrm{~g}$.) was con? tracted and showed a mild diffuse amyloid change.

The kidneys (left $95 \mathrm{~g}$.; right $110 \mathrm{~g}$.) showed the appeare 


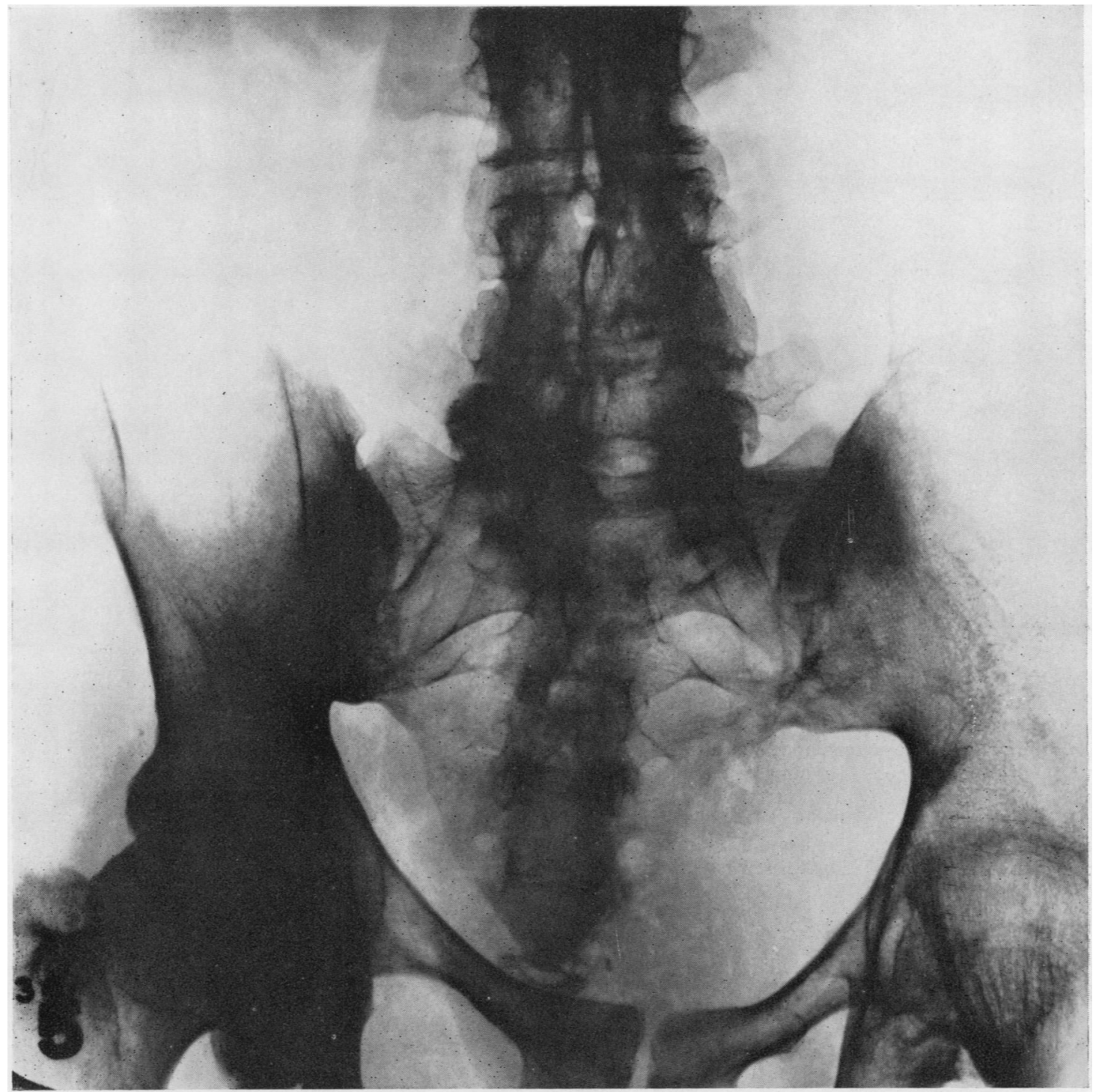

Fig. 1.- $X$ ray showing bony ankylosis of both sacro-iliac joints and of left hip joint on January $27,1953$.

ance of amyloid contracted (or "small amyloid") kidneys. The capsules were lightly adherent; the surface was a mottled grey-white and was granular. The cut surface showed prominent glomeruli throughout the cortex. The corticomedullary junction was blurred and the medullary fat increased. The vessels were prominent. Microscopically there were deposits of amyloid around the afferent arterioles, and glomerular and intertubular capillaries, and in the basement membrane of the tubular epithelium (Fig. 2, overleaf).

There was irregular interstitial fibrosis with alternating areas of tubular atrophy and dilatation. The tubules contained hyaline material and altered blood pigment.

The adrenal glands showed amyloid substance around the cortical capillaries with atrophy of the cells of the zonae reticulosa and fasciculata. The cells of the zona glomerulosa were vacuolated and contained lipoid. The medulla was normal. The thyroid showed a moderate increase in stroma with marked lymphocytic infiltration and some atrophy of vesicles. The pituitary, pancreas, and testes showed no abnormality. The hip, sacroiliac, and intervertebral joints showed advanced changes with bony ankylosis. There was calcification of 


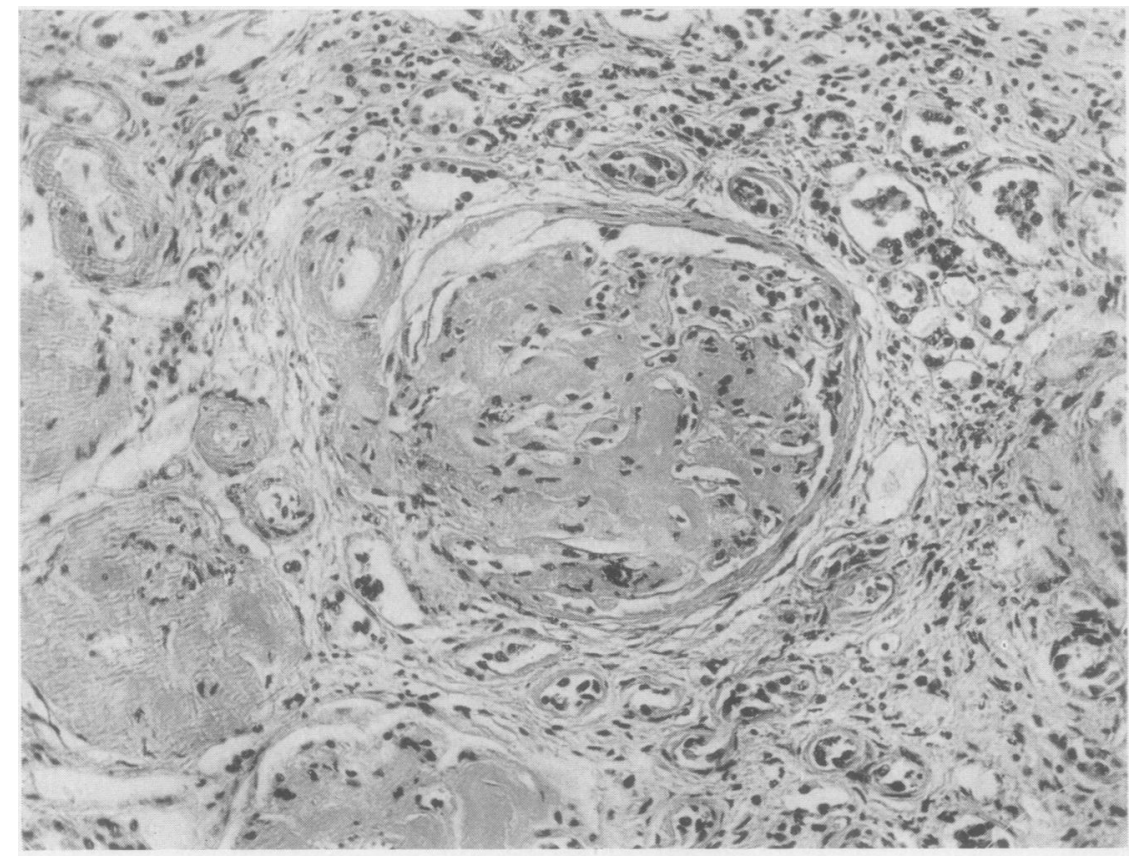

Fig. 2.-Renal cortex showi ing enlarged glomeruluis with sub-endothelial deø posits of amyloid around the glomerular capillarie and the afferent arteriole. (Haematoxylin-eosin) $\times 200$.

the interspinous ligaments in the thoracic region. Sections of the 11 th costovertebral and costotransverse joints showed no ankylosis. The anterior and posterior longitudinal spinal ligaments appeared normal.

The presence of deposits of amyloid was confirmed by staining fresh material with a watery solution of iodine, and by staining sections prepared from tissues fixed in formol-saline with Congo red and with methyl violet, using the method described by Missen and Taylor (1956).

\section{Discussion}

Several points are illustrated by this case. The importance of proteinuria as an early sign of amyloid disease is again shown. It was noted 8 years after the onset of symptoms of ankylosing spondylitis and was unaccompanied by hepatic or splenic enlargement. Malignant hypertension developed in the next 3 years and death occurred after thirteen years illness.

The Congo red test gave useful clinical confirmation of the diagnosis, but a negative result does not rule out the possibility of amyloid disease (Selikoff, Paterson, and Herschfus, 1949). The importance of histological confirmation of the diagnosis has been stressed by Teilum and Lindahl (1954) and Missen and Taylor (1956) have pointed out the importance of using a metachromatic staining reaction in addition to the Congo red method. In histological preparations the latter dye may be taken up by materials other than amyloid.
Renal involvement is a common mode of deathîn secondary amyloidosis. Of the seventeen cases analysed by Teilum and Lindahl, death was dueste renal amyloidosis in seven, and in the series reported by Gedda (1955), the nine cases of amyloidosis al died as a result of renal involvement.

The development of hypertension in amyloidosi\& is rare. Fishberg and Oppenheimer (1930) con $\vec{\circ}$ firmed this and noted that hypertension did no $\$$ occur in cachectic subjects. They suggested that cachexia might prevent the development of hyper: tension, even when many other factors predisposing to this condition were present. They also foun $\mathbb{P}^{\mathbb{P}}$ that hypertension due to amyloidosis is invariably associated with the amyloid contracted kidney. In the case here reported, hypertension developed in क्f non-cachectic patient who was found at autopsy to have amyloid contracted kidneys. The bloof pressure in our patient fell during the last few month of life; Liedholm (1940) suggested that adrenal in volvement might prevent hypertension, but the adrenal changes were probably insufficient tơ account for the fall in pressure.

It has been suggested that the occurrence of the् amyloid contracted kidney is related to the late stages of amyloid nephrosis and that hypertensios may occur once this lesion is fully establishedक although the coexistence of fever and infection may reduce the intensity of the hypertension or even prevent it (Pickering, 1955). 
Gedda found that nine of his series of eleven cases died of renal amyloidosis; of these seven had contracted amyloid kidneys, and three of the seven had hypertension. He suggested that hypertension acted as a compensatory mechanism in renal insufficiency due to amyloidosis by increasing the filtration pressure.

If the contracted kidney were the result of hypertension it would appear to be reasonable to expect to find cases in which hypertension was accompanied by little or no contraction (as in essential hypertension). This is not so, except in late renal failure in the non-contracted kidney (Zuckerbrod, Rosenberg, and Kayden, 1956), nor is the contracted kidney invariably associated with raised blood pressure. It is possible that both contraction and hypertension are the result of progressive renal ischaemia, the occurrence of hypertension being dependent on additional factors which are either not present or are inhibited in the majority of cases.

In our case there were changes in other organs, namely the liver and spleen, which showed atrophy and fibrosis in the absence of chronic venous congestion, suggestive of a similar process.

Renal insufficiency, although constantly found when the kidneys are contracted, can occur in the absence of this change (Noble and Major, 1929).

The absence of cachexia in our case would seem to confirm that hypertension is more likely to occur in well-nourished subjects, but a study of the literature shows that cases have been reported in amyloidosis associated with cachexia (Noble and Major, 1929), including one described by Fishberg and Oppenheimer (1930).

The association of amyloidosis and ankylosing spondylitis must be rare. In rheumatoid arthritis a link has been suggested between the hyperglobulinaemia and plasmacytosis, and the occurrence of amyloid disease. Pillers and Marks (1956) found an increased plasma cell content of the bone marrow in ten out of 28 cases of ankylosing spondylitis, but no serum protein estimations were made. Our case showed hyperglobulinaemia on the one occasion that the serum proteins were estimated, but examination of the bone marrow from several sites showed no increase in plasma cells.

In the differential diagnosis, irradiation nephritis followed by secondary amyloidosis was considered to be an unlikely course of events owing to the relatively small dose of $x$-rays employed. Kunkler, Farr, and Luxton (1952) stated that a homogeneous dose of $2,300 \mathrm{r}$ to the whole of both kidneys may lead to the development of hypertension and renal failure. The total dosage given here was $1,750 \mathrm{r}$ in 1945, and $1,500 \mathrm{r}$ in 1951 (after the onset of albuminuria), but only a very small amount arising from scatter of $x$-rays to the lumbar spine would have reached the kidneys. The latent period preceding the development of irradiation nephritis is only 6 to 12 months, and not several years as in this case.

\section{Summary}

The clinical and pathological features of fatal amyloid disease in a case of ankylosing spondylitis are described and discussed.

We should like to express our thanks to Dr. F. Dudley Hart for his help, and for permission to publish details of this case.

\section{REFERENCES}

Fearnley G. R., and Lackner, R. (1955). Brit. med. J., 1, 1129. Fishberg, A. M., and Oppenheimer, B. S. (1930). Arch. intern. Med. 46, 901 .

Kunkler, P. B., Farr, R. F., and Luxton, R. W. (1952). Brit. J. Radiol., 25, 190.

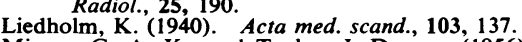

Missen, G. A. K., and Taylor, J. Duncan (1956). J. Path. Bact., 71, 179 .

Noble, J. F., and Major, S. G. (1929). Arch. Path. (Chicago), 8, 762.

Pickering, G. W. (1955). "High Blood Pressure", 1st ed., p. 357. Churchill, London.

Pillers, E. M. Kingsley, and Marks, J. (1956). Lancet, 1, 722.

Pillers, E. M. Kingsley, and Marks, J. (1956). Lancet, 1, 722. dent. Ass., 39, 159.

Teilum, G., and Lindahl, A. (1954). Acta med. scand. 149, 449.

Wichmann, G. (1893). Beitr. path. Anat., 13, 487.

Zuckerbrod, M., Rosenberg, B., and Kayden, H. J. (1956). Amer. J. Med., 21, 227.

\section{Maladie amyloïde complicant la spondylarthrite ankylosante \\ RÉSUMÉ}

On décrit et on discute les caractères cliniques et anatomo-pathologiques de la maladie amyloïde mortelle dans un cas de spondylarthrite ankylosante.

\section{Enfermedad amiloide complicando la espondilartritis anquilosante \\ Sumario}

Se describen y discuten los rasgos clínicos y anatomopatológicos de la enfermedad amiloide con terminación fatal en un caso de espondilartritis anquilosante. 